\title{
Tourist focus of handmade souvenirs: two markets case of Acapulco
}

\author{
Enfoque turístico de los souvenirs artesanales: caso de dos mercados de Acapulco \\ ROJAS-COPA, Aline Estrella†*, NIÑO-GUTIÉRREZ, Naú Silverio, NIÑO-CASTILLO, Isaías Naú \\ and NIÑO-CASTILLO, Jacob Elías
}

Universidad Autónoma de Guerrero. Faculty of Tourism. Mexico.

ID $1^{\text {st }}$ Author: Aline Estrella, Rojas-Copa / ORC ID: 0000-0002-2874-818X, CVU CONACYT ID: 777001

ID $1^{\text {st }}$ Coauthor: Naú Silvero, Niño-Gutiérrez / ORC ID: 0000-0001-9250-0798, CVU CONACYT ID: 32380

ID $2^{\text {nd }}$ Coauthor: Isaías Naú, Niño-Castillo / ORC ID: 0000-0003-0728-3798, CVU CONACYT ID: 919978

ID $3^{\text {rd }}$ Coauthor: Jacob Elías, Niño-Castillo / ORC ID: 0000-0002-0575-5336, CVU CONACYT ID: 919977

DOI: $10.35429 /$ EJM.2020.24.11.24.34

Received January 25, 2020; Accepted June 30, 2020

\begin{abstract}
The main objective was to synthesize the importance of handicrafts among tourists who visited the markets "El Pueblito" and "La Diana" in Acapulco, Guerrero, Mexico. The methodology used was cabinet work between September 2018 and March 2019 in order to compile the existing documentary information on the study categories: souvenirs, crafts and tourism. A questionnaire made up of 26 items was also prepared, of which the responses of the most relevant that contribute to the achievement of the general objective are presented here. Among the results, it was found that the products that are most in demand among tourists are those derived from coconut, namely: coconut sweets, decorative items based on the said vegetable product of natural origin, among others. The most relevant conclusion was that from the economic point of view, handicrafts represent an important source of income for the members of the native groups that make handicrafts on a small scale with affordable costs. This research contributes to the recent international bibliography on artisan souvenirs that are elaborated with love, enthusiasm and identity, by people from the population groups originating from the various parts of the world.
\end{abstract}

\begin{abstract}
Resumen
El objetivo central fue sintetizar la importancia de las artesanías entre los turistas que visitaron los mercados "El Pueblito" y "La Diana" en Acapulco, Guerrero, México. La metodología empleada fue trabajo de gabinete entre septiembre de 2018 y marzo de 2019 a fin de recopilar la información documental existente sobre las categorías de estudio: souvenirs, artesaías y turismo. También se elaboró un cuestionario integrado por 26 ítems de los cuales aquí se presentan las respuestas de los más relevantes que aportan al logro del objetivo general. Entre los resultados se encontró que los productos que tienen mayor demanda entre los turistas son los derivados del coco a saber: dulces de coco, artículos decorativos con base el dicho producto vegetal de origen natural, entre otros. La conclusión más relevante fue que desde el punto de vista económico, las artesanías representan una fuente de ingreso importante para los integrantes de los grupos originarios que elaboran las artesanías a pequeña escala con costos accesibles. Esta investigación contribuye a la bibliografía internacional reciente sobre souvenirs artesanales que elaboran con todo cariño, entusiasmo e identidad, personas de los grupos de población originarios de los diversos sitios del orbe.
\end{abstract}

Artesanías, Souvenirs, Turismo

Handcrafts, Souvenirs, Tourism

Citation: ROJAS-COPA, Aline Estrella, NIÑO-GUTIÉRREZ, Naú Silverio, NIÑO-CASTILLO, Isaías Naú and NIÑOCASTILLO, Jacob Elías. Tourist focus of handmade souvenirs: two markets case of Acapulco. ECORFAN Journal-Mexico 2020. 11-24:24-34.

\footnotetext{
* Correspondence to Author (email: alinestrella_7@ @otmail.com)

$\dagger$ Researcher contributing first author.
} 


\section{Introduction}

Handicrafts are a folkloric product that reflect the idiosyncrasy of the population that designs them to such a degree that it reflects their individual and collective identity, which encompasses three dimensions: The artisan, artisan activity and crafts (Navarro, 2012 cited by Poveda, 2020).

The crafts are made by hand by people from different parts of the world, it gives them identity and is an extension of their customs, culture and way of appreciating their relationship with nature. That is why, "the care and preservation of the environment is currently one of the most important factors to take into account when implementing a micro-business, for this reason the project will focus on using natural resources" (Singón, 2016) . An example of these resources is the coconut as a fundamental element in making handicrafts.

Handicrafts are a relevant resource for the tourism sector among the population that lives in ports and coastal cities on the Pacific Ocean, as is the case in Mexico, where the native population takes advantage of the natural resources provided by nature itself, with which they seek to value the local folk customs and traditions.

According to Arroyo and Terán (2017), a large part of the crafts that are made today come from some natural derivative related to the environment, which highlights the need for research aimed at the sustainability of natural resources and their controlled exploitation, focused on the sustainability of the activity. Sic., Trujillo and Arias (2013) point out that in particular the coconut shell is considered a waste, however, it has a high economic-environmental value, based on success stories in different parts of the world.

The main objective of the essay is to synthesize the importance of handicrafts among tourists who visited the markets "El Pueblito" and "La Diana" in Acapulco, Guerrero, Mexico. The guiding question was: What are the artisan souvenirs that are most in demand among national and foreign tourists who visited Acapulco between 2018 and 2019?
This study is justified because there is currently little literature that relates visitors to artisan souvenirs such as sweets, oil, soap, among other products made from coconut. This research will emphasize the responses of national and foreign tourists who acquired artisan souvenirs among the tenants of the markets "El Pueblito" and "La Diana", who are the ones who offer the souvenirs.

The methodology used was cabinet work between September 2018 and March 2019 in order to compile the existing documentary information on the study categories: souvenirs, crafts and tourism. A questionnaire made up of 26 items was also prepared, of which the responses of the most relevant that contribute to the achievement of the general objective are presented here.

As feedback to the cabinet work, field work was carried out between April and December 2019. Where 673 questionnaires were applied to national and foreign tourists. As well as, the analysis of the data and interpretation of the results to finally elaborate the writing.

In this sense, it is necessary to take into account that the Ministry of Agriculture and Rural Development (SAGARPA), in 2013 the State of Guerrero in particular produced 3,061 tons of coconut, which is why said entity was ranked eighth in the country in terms of a total of 32 states (SAGARPA, 2015).

Within the literature reviewed, it was found that the production of handicrafts is a viable local strategy from rural tourism, according to Lechuga, González and Domínguez (2020).

In the south of Mexico, where Guerrero is located, the original population designs various artisan representations made from coconut, in the city of Acapulco and neighboring municipalities who consider these artifacts the fruit of the symbiosis between culture and nature, some examples of these crafts are figures of: chimpanzees, dolphins, herons, armadillos, snakes and parakeets (Figure 1). 


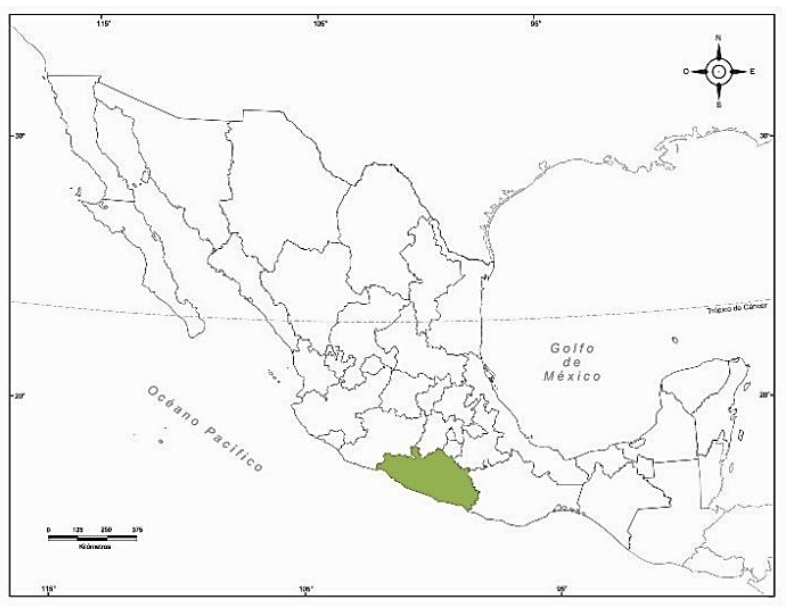

Figure 1 Guerrero geographical location Source: Niño, 2014

In this essay, the correlation between the souvenirs made from the coconut shell and the profile of the tourist who acquires them was sought, in addition, it synthesizes the economicsustainable characteristics that allow to show an attractive and innovative product that meets the needs required by the buyers.

Handicrafts boost the economy of the tenants by generating an attraction through the offer of products that serve as souvenirs to visitors; Within this type of resources, there are different topics that can be addressed, such as handicrafts made from seashells, sought after by tourists, and an innovative element is handicrafts based on skin or fish scales; It seeks to reuse a discarded resource, which is decorated to offer them as: necklaces, bracelets and earrings. While the leather is tanned through a special process to make purses, huaraches, bracelets and other items (Figure 2).

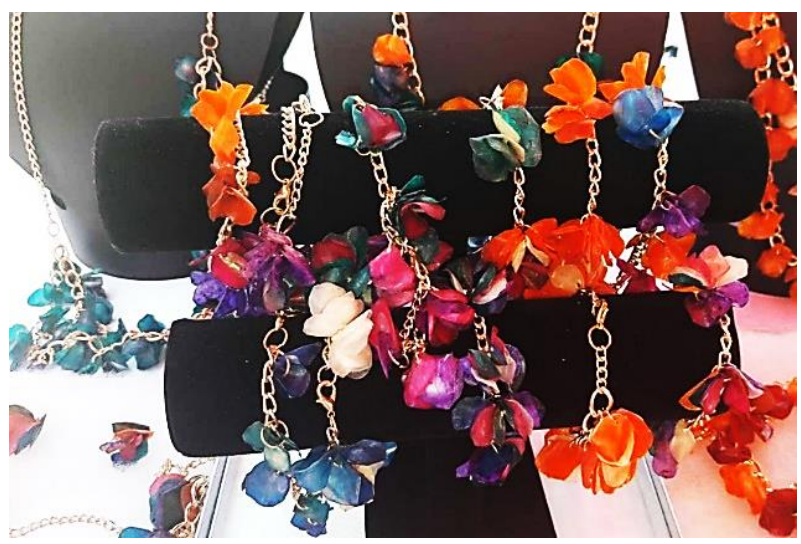

Figure 2 Handicrafts made from fish scales Source: Rojas, 2018
Regarding the definition of artisanal product granted by the General Directorate of Popular Art, of the Ministry of Public Education, it refers to "any action that generates articles made by hand with the support of simple tools." This implies the transmission of knowledge and practices from generation to generation (Bonfil, 2001), also the use of natural resources preferably without transformation present in the various sites and regions of Guerrero (UNIFEM, 1997); as seen in Figure 3, which represents a hand-carved coconutbased heron.

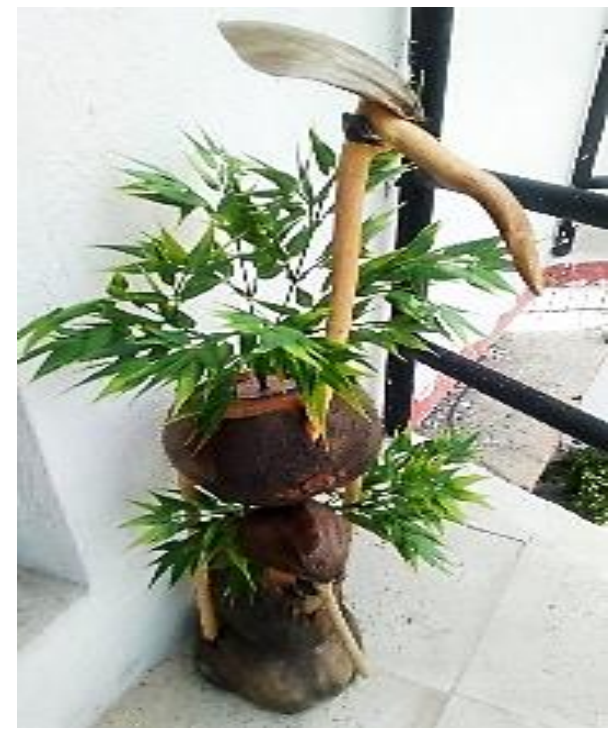

Figure 3 Souvenir made from coconut Source: Rojas, 2018

On the other hand, the biophysical characteristics in which these souvenirs are produced will be detailed, an issue that has been relegated by other investigations, projects and monographic studies that emphasize the economic part of this subject. "Souvenirs as products that seek to maintain the authenticity of the local culture have in tourism a great ally of symbolic consumption, experience and representativeness of the visited destination" (Quille \& Urgilés, 2020: 27).

In this research, it is considered that the study and promotion of traditional Guerrero crafts (Figure 4), their innovation and commercialization are highly significant for national and foreign tourism that visits this beach destination, since it is an activity that helps in protect and promote the cultural diversity of Guerrero through the traditional knowledge of the Acapulqueños, at the same time that it collaborates in the family income of the artisans who make them, by promoting a culture of respect for the environment. 


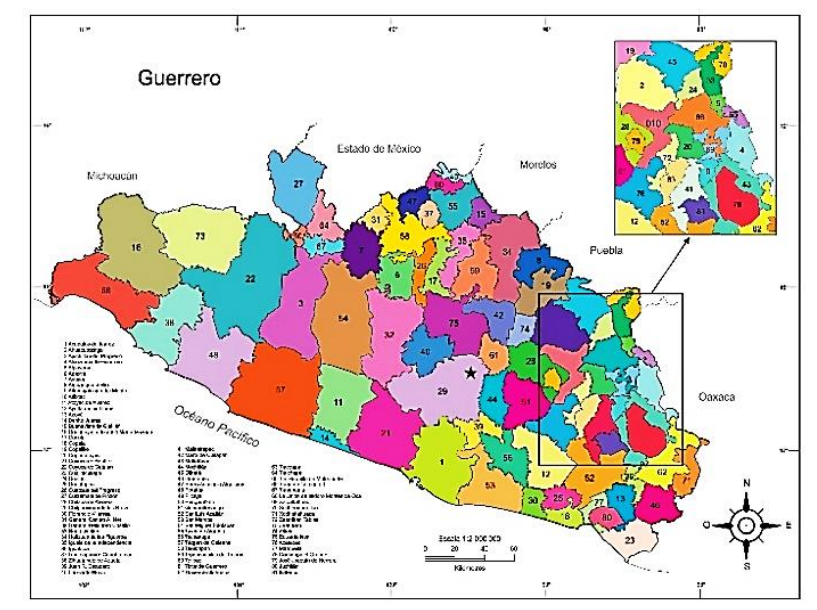

Figure 4 Municipal division of the state of Guerrero Source: Self made

\section{Methodology}

In the first place, the reading, selection and analysis of books, printed guides that indicate the attractions of the port of Acapulco, magazines and publications that advertise packages and offers for tourists were used, as well as information brochures that detail the natural beauties and artificial as local attractions (Lesur, 2006). Also, existing digital and printed information was used on: palm trees, coconut, coconut-based crafts, environment (Niño, 2014), tourism (Niño \& Bergeret, 2012) and sustainability (Ruiz \& Niño, 2014). This work was complemented with participant observation and application of a questionnaire.

The work method was based on the geographical approach by interrelating physical, biotic, economic, social and environmental factors. Which allowed the analysis of the symbolic phenomenon of the souvenir. This contributed to a better understanding of the "memories" that tourists acquire when visiting the port of Acapulco.

For this, the research scope was analytical with a mixed methodological design. The mixed design used comprised two stages: the first, corresponded to the reading, selection and analysis of existing digital and printed information on: palm trees, coconut, coconutbased handicrafts, environment (Ibídem, 2014), tourism (Ibídem, 2012) and sustainability (Ibídem, 2014).
The second stage included field work in which photographic shots were taken in the months of December 2018-January 2019. The two markets of the study area were visited and participant observation was made, between the month of March of that year., in which a predominance was observed among national visitors over foreigners, who attended to buy: handicrafts, sea shell ornaments and combs and tamarind sweets, among others.

The techniques that supported the study were qualitative since participant observation and the application of a questionnaire comprised of eight semi-structured questions were used. In addition to quantitative techniques through the consultation of databases referring to the characteristics of the natural heritage, souvenirs, use of natural plant resources and national and international tourism. In this cabinet work, we also resorted to consulting satellite images, taking photographic images, and reviewing printed and digital cartography. In addition to field work carried out in the markets "El Pueblito" and "La Diana" of the port of Acapulco de Juárez, Guerrero, held from December 2018 to November 2019, in that period, 673 questionnaires and various photographic shots were raised.

The instrument or questionnaire comprised ten questions with the possible answers of yes or no and which ones, to determine the percentage of national or foreign tourists, on the one hand, who attend the study area; In addition to the average age of the tourists who go to the markets "El Pueblito" and "La Diana", in order to obtain answers about what type of national or foreign tourists like to buy souvenirs, also determine the country of origin of the tourist ; average number of nights spent overnight; determine gender and percentage; the economic spill during your stay; schooling of visitors; time spent in the study area.

The finite population formula was chosen through the responses of key informants from the markets "El Pueblito" and "La Diana".

The formula that was used to target the finite population to which it was applied to tourists, men and / or women, nationals and / or foreigners, over 16 years of age, souvenir buyers in the markets "El Pueblito and" La Diana " from Acapulco, according to what is proposed by Bomba, F. (2018).

Where: 
$\mathrm{n}=$ Size of the sample sought

$\mathrm{N}=$ Size of the population or universe

$\mathrm{Z}=$ Statistical parameter that depends on the Confidence Level (NC)

$\mathrm{e}=$ Maximum accepted estimation error (success)

$\mathrm{p}=$ Probability of the event being studied

$q=(1-p)$ Probability that the event studied will not occur

For the case study:

$\mathrm{N}=1,825$ Universe of study (5 people a day between the two markets for 365 days a year). $(95 \%)$

$Z=1.96$ Confidence level of the sample

$\mathrm{e}=3 \%$ Estimated error

$p=0.5$ Probability of success $(50 \%)$

$q=0.5$ Probability of failure $(50 \%)$ follows:

For the use of Equations, indicate as

$$
\begin{aligned}
& n=\frac{1825 * 1.96^{2} * 0.5 * 0.5}{\left(3^{2} *(1825-1)\right)+1.96^{2} * 0.5 * 0.5} \\
& n=\frac{1825 * 3.84 * 0.5 * 0.5}{(0.0009 *(1824))+3.84^{2} * 0.5 * 0.5} \\
& n=\frac{1752}{2.60} \\
& n=673.84 \text { questionnaires }
\end{aligned}
$$

\section{Results}

In order to achieve the successful promotion of quality organic handicrafts, it is advisable to have a tourism marketing that reinforces the distribution channels that imply "making the products and services of the producers (sic) available to the consumer, thus specifying the sale and making its collection "(Padilla and Tacuri, 2020: 58) of the products that are for sale, as in this case based on coconut.
In this order of ideas, the questionnaires applied were 674 and in a hierarchical way they were integrated as follows: 234 visitors from CDMX; 116 of EDOMEX; 80 from the state of Puebla; 60 from the interior of the state of Guerrero, 40 from the state of Morelos; 28 from the state of Querétaro; 20 come from Guanajuato; 15 from Nuevo León, 12 from Oaxaca; 9 from Tamaulipas; 9 from Baja California, 9 from Jalisco and 9 from Michoacán, 6 from Cuba, 6 from Yucatán, 6 from Canada, 6 Argentina and 6 USA; finally 1 from Tabasco, 1 from SLP and 1 from Veracruz.

As for the souvenirs made based on the natural resources present in the Acapulco region or in its surroundings by tourists, they argued that they had acquired: coconut sweets, tamarind pulp, clothing, key rings and sea shell lamps, among others. .

In the market "El Pueblito" stands out for the bulk sale of sweets such as sugary tamarind pulp and enchiladas, cocadas, palanquetas, coconut sweets, coconut-based herons. On the other hand, in "La Diana", bathing suits, typical clothes, glasses, life jackets, bags and monkeys made of coconut, feathers, boats, key rings, among others.

According to the results obtained by means of the questionnaire technique, it was obtained that in the market "El Pueblito" stands out for the bulk sale of sweets such as sugary tamarind pulp and enchiladas, cocadas, palanquetas, coconut sweets, herons-based coconut. On the other hand, in "La Diana", bathing suits, typical clothes, glasses, life jackets, bags and coconut-based monkeys, feathers, boats, key rings, among others (Table 1).

\begin{tabular}{|l|r|r|}
\hline \multicolumn{1}{|c}{ Souvenirs } & \multicolumn{1}{c}{$\begin{array}{l}\text { Number } \\
\text { repetitions }\end{array}$} & \multicolumn{1}{c|}{$\begin{array}{c}\text { of of } \\
\text { repetitions }\end{array}$} \\
\hline Coconut sweets & 128 & 18.9 \\
\hline Tamarind pulps & 120 & 17.8 \\
\hline Clothing & 104 & 15.4 \\
\hline Keychains & 72 & 10.6 \\
\hline Sea shell lamps & 32 & 4.7 \\
\hline cocadas & 32 & 4.7 \\
\hline Guaraches & 24 & 3.5 \\
\hline Hats & 16 & 2.3 \\
\hline Little boxes & 8 & 1.1 \\
\hline Wallets & 8 & 1.1 \\
\hline Necklaces & 8 & 1.1 \\
\hline Frogs & 8 & 1.1 \\
\hline Jewelry boxes & 8 & 1.1 \\
\hline Coconut & 8 & 1.1 \\
planters & & \\
\hline
\end{tabular}

Table 1 Local souvenirs

Source: Rojas, 2019 
Among the decorative pieces most in demand by tourists visiting this beach destination were: clothing, key rings, sand bottles, bracelets, among others.

Based on the results of the questionnaires, it was obtained that the most preferred souvenirs among tourists from the port of Acapulco invest between 60 and 133 Mexican pesos, where sweets, key rings, clothes and bags, based on coconut, were in greater demand as raw material (Table 2).

\begin{tabular}{|l|r|r|}
\hline \multicolumn{1}{|c}{ Souvenirs } & \multicolumn{1}{c|}{$\begin{array}{c}\text { Number of } \\
\text { repetitions }\end{array}$} \\
\hline Keychains & 196 & 29.0 \\
\hline Clothing & 126 & 18.6 \\
\hline Coconut-based bags & 42 & 6.2 \\
\hline Shells & 28 & 4.1 \\
\hline Feathers & 28 & 4.1 \\
\hline Wallets & 14 & 2.0 \\
\hline Frogs & 14 & 2.0 \\
\hline Skulls & 14 & 2.0 \\
\hline Necklaces & 14 & 2.0 \\
\hline Hats & 14 & 2.0 \\
\hline Jewelry boxes & 14 & 2.0 \\
\hline Cups & 14 & 2.0 \\
\hline Boats & 14 & 2.0 \\
\hline Sweets & 14 & 2.0 \\
\hline Tamarinds & 14 & 2.0 \\
\hline Hammocks & 14 & 2.0 \\
\hline Clay jugs & 14 & 2.0 \\
\hline Lamps & 14 & 2.0 \\
\hline
\end{tabular}

Table 2 Souvenirs most frequently purchased among tourists

Source: Rojas, 2019

The challenges presented by public policy programs for tourism and artisans in the state of Guerrero are:

To know the real register of the number of artisans in the state.

Lack of support programs for training, updating and distribution of artisan merchandise.

Greater dissemination of human talent in making regional handicrafts.

Economic support from the State Social Development Secretariat.

Improve the image of the facilities where artisanal merchandise is sold.

Promote the culture of "Buy Our Own".
Tourists who visited this beach destination argued that they invest a minimal part of their economic resources for the acquisition of local handicrafts, among the amounts reported by those interviewed range between: \$ 380, \$ 355 and \$ 285 Mexican pesos (Table 3).

\begin{tabular}{r|r|r|}
\multicolumn{1}{|c}{ Coin } & \multicolumn{1}{c}{$\begin{array}{c}\text { Number of } \\
\text { repetitions }\end{array}$} & $\begin{array}{c}\text { \% of } \\
\text { repetitions }\end{array}$ \\
\hline$\$ 380$ & 15 & 2.2 \\
\hline$\$ 355$ & 15 & 2.2 \\
\hline$\$ 285$ & 15 & 2.2 \\
\hline$\$ 200$ & 15 & 2.2 \\
\hline$\$ 190$ & 15 & 2.2 \\
\hline$\$ 152$ & 15 & 2.2 \\
\hline$\$ 140$ & 15 & 2.2 \\
\hline$\$ 133$ & 45 & 6.6 \\
\hline$\$ 95$ & 135 & 20.0 \\
\hline$\$ 60$ & 15 & 2.2 \\
\hline$\$ 50$ & 60 & 8.9 \\
\hline$\$ 30$ & 300 & 44.5 \\
\hline
\end{tabular}

Table 3 Amounts allocated by tourists to the purchase of handicrafts

Source: Rojas, 2019

Of the 674 interviewed, in general, tourists recommend to buy handicrafts in the markets "El Pueblito" and "La Diana", because they are located on the coastal avenue Miguel Alemán in downtown Acapulco (Figure 5).

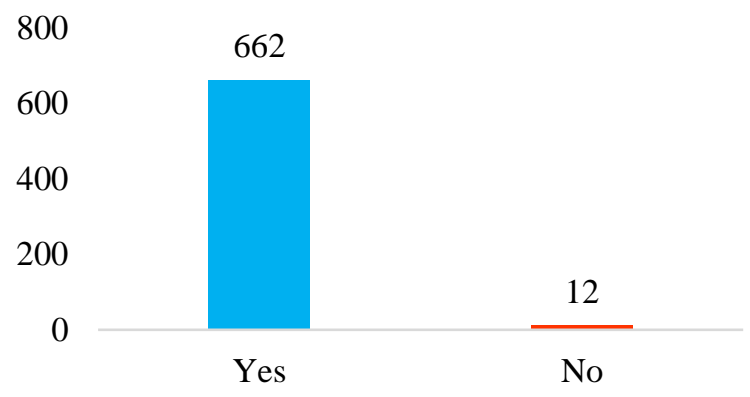

Figure 5 Would you recommend the market Source: Rojas, 2019

This final control question, evidenced among tourists the importance of acquiring local handcrafted souvenirs / souvenirs and a smaller number of tourists simply expressed that the acquisition of a souvenir from this beach destination is not important because they are busy in your congress and convention tourism (Figure 6).

ROJAS-COPA, Aline Estrella, NIÑO-GUTIÉRREZ, Naú Silverio, NIÑO-CASTILLO, Isaías Naú and NIÑO-CASTILLO, Jacob Elías. Tourist focus of handmade souvenirs: two markets case of Acapulco. ECORFAN Journal-Mexico 2020 


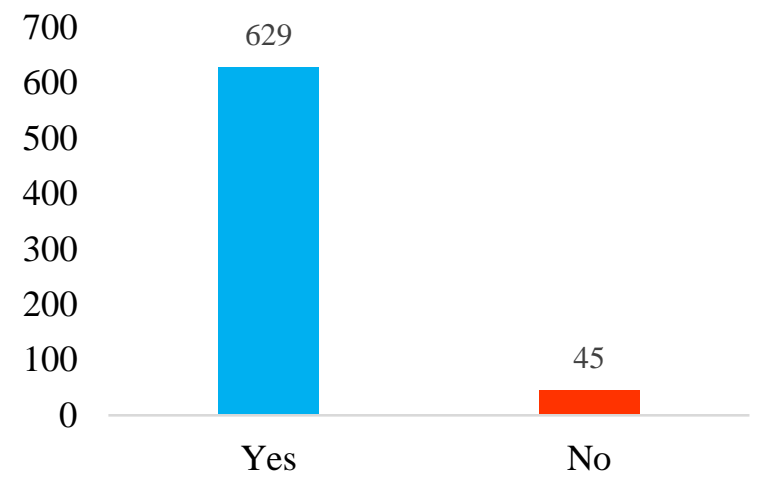

Figure 6 Know the importance of the souvenir Source: Rojas, 2019

The results for question 22 of a total of 26 items of the questionnaire used are shown below. The question was: Does Acapulco associate it with souvenirs made with sand, coconut or palm? Of which $65 \%$ answered that, if there is a close association, while the remaining $35 \%$ do not associate them because it is something new for them (Figure 7).

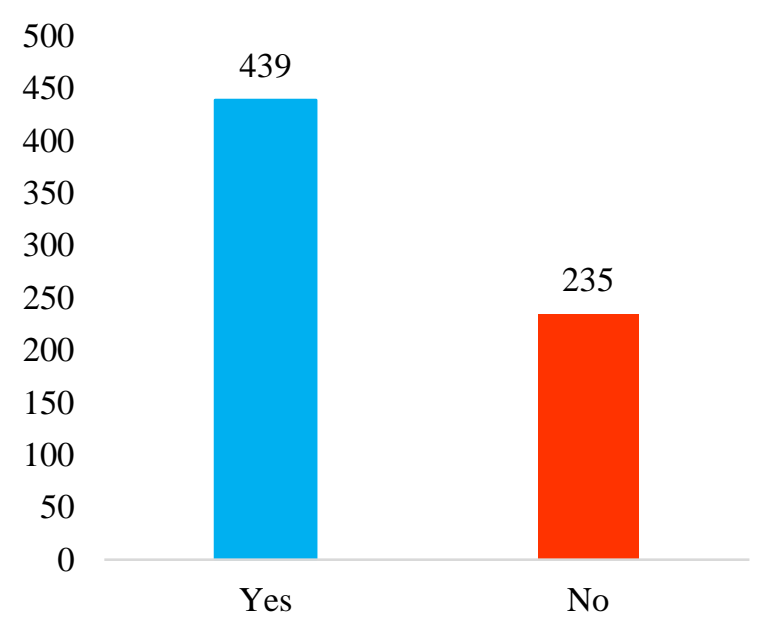

Figure 7 Associate Acapulco with palm, sand or coconut souvenirs

Source: Rojas, 2019

Question 23 refers to the following question: Do you associate Acapulco with organic souvenirs? Of those surveyed, only $37 \%$ answered that, if they link this beach destination with organic souvenirs because there is still abundant biodiversity, while $63 \%$ answered that the port of Acapulco still needs more consolidation regarding souvenirs based on coconut (Figure 8).

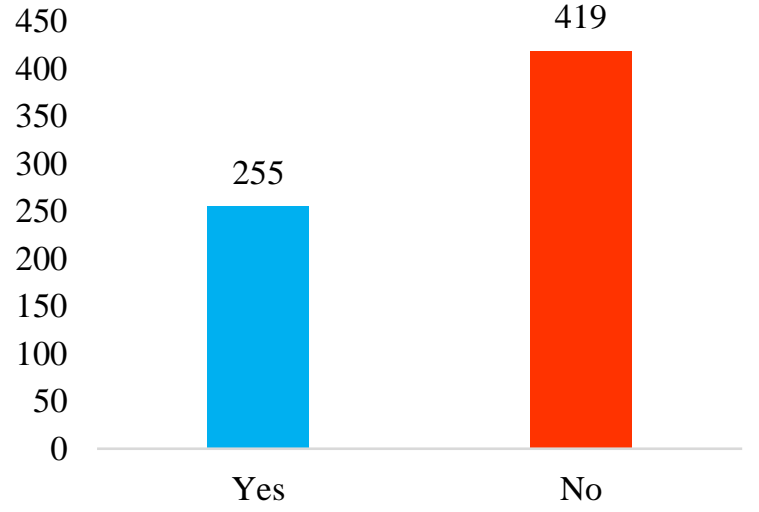

Figure 8 Associate Acapulco with organic souvenirs Source: Rojas, 2019

Question 24 of the applied questionnaire refers to: Was your experience with the climate of Acapulco as expected? The answers were conclusive in the sense that $63 \%$ mentioned that, yes and only $27 \%$ said that they did not, given that they found an atmospheric time with clouds and copious precipitations. Which reduced the possibilities of enjoying the beach, sun and sand (Figure 9).

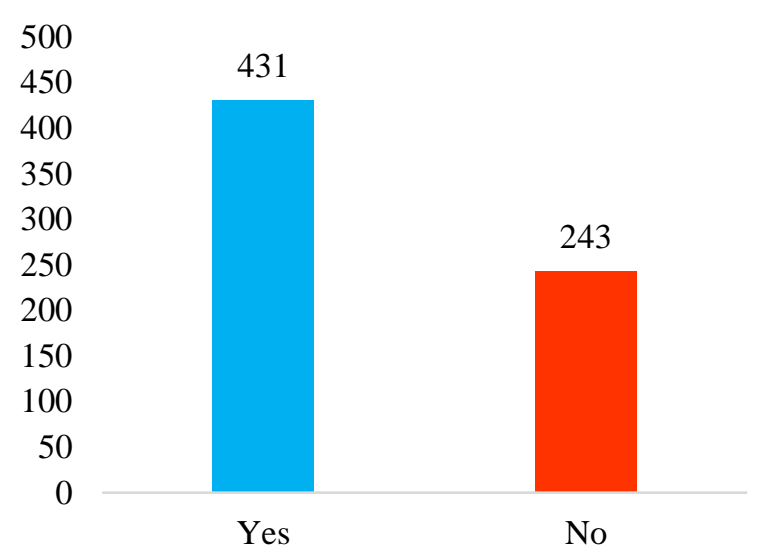

Figure 9 The Acapulco weather was as expected Source: Rojas, 2019

Question 26 is: Do you support the environment by buying souvenirs based on organic waste such as coconut, among others? The responses were two thirds (64\%) said yes and $36 \%$ said no, because they stated that souvenirs based on coconut need promotion (Figure 10). 


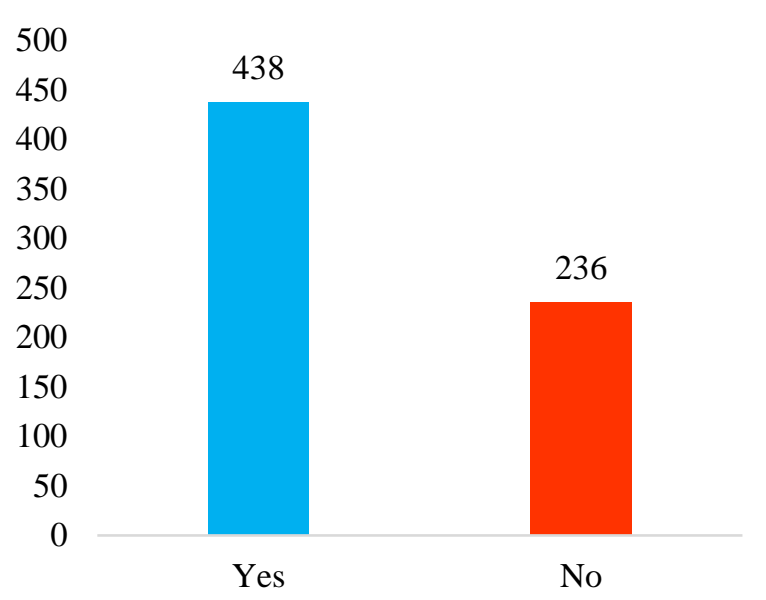

Figure 10 Support the environment by buying souvenirs based on organic waste

Source: Rojas, 2019

\section{Discussion}

During the research process it was detected that one of the points to be strengthened in the development of handicrafts is the marketing stage, since tourists request discounts on the costs at which the products are offered. Therefore, Acapulco artisans know the costs of their inputs, as well as their target market, but feel somewhat unmotivated when tourists do not cover the real cost of their effort.

The tenants commented that they make their crafts, but the hoarders request to trade their products and after the sale they promise to pay them, which in many cases does not happen, to the detriment of the cultural identity of those who make them, the symbol and the cultural meaning of the pieces.

Some artisans from the "El Pueblito" market stated that the artisan products have unique, original and remarkable characteristics, which translates into a competitive advantage for the artisans of Guerrero. However, currently to continue in the market competition they resort to innovation and new designs, such as, for example: making covers for Ipad, covers for laptops, tortilleros, baskets for clothes, bags for girls, cell holders, pens, vases, baskets for fruits, jewelry boxes, portfolios, without sacrificing the elements of identity and tradition. Designing a craft object requires a process of trial and error, since you have to start with drawings, continue with models, and finally the process ends with the prototype (Covarrubias, 2018).
Although it is necessary to criticize that from an economic point of view the consumption or investment made by tourism in the "El Pueblito" and "La Diana" handicraft markets, it is hardly significant given that the purchases made by tourists are minimal., although they do contribute to the family income of the small local merchant, artisan and restorer.

The handicrafts found in the markets "El Pueblito" and "La Diana" have a wide variety of functions, including decorative, souvenir, nostalgia, identity, culture, as well as beautiful and unique and even a utilitarian, domestic, ornamental value. and clothing. Local artisans located in the Zapata, Vacacional, Renacimiento, Plan de los Amates neighborhood in the municipality of Acapulco, use unique methods to make their crafts that they have learned through several generations, through family traditions to create clothing items, jewelry, sweets, souvenirs and carving of figures on the stem of the coconut. In this beach destination you can get these works of art in: Zócalo, central market, "Parazal" market, central de abastos, "El Pueblito," La Diana ", the house of culture and in general, outside the municipality of Acapulco in the magical town of Guerrero, Taxco (Figure 11).

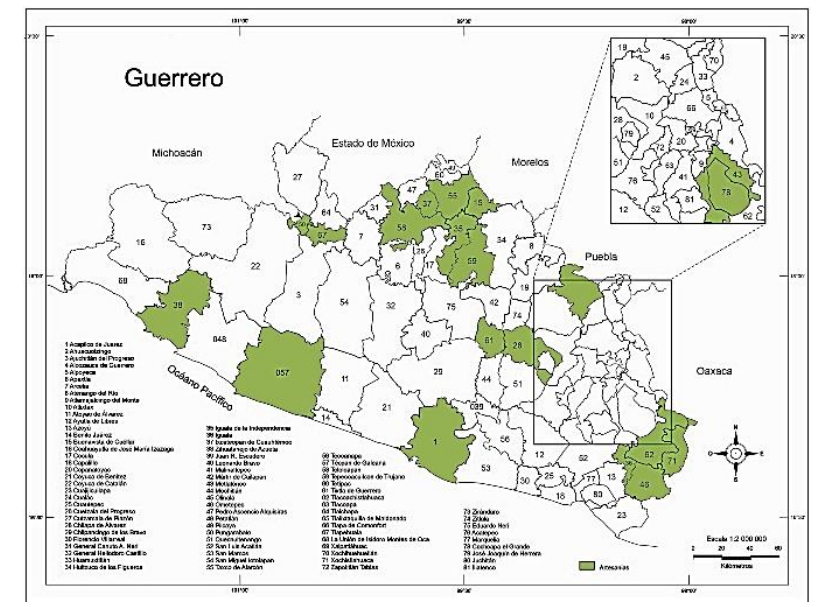

Figure 11 Municipalities where guerrerenses crafts are made Source: Self made

Mexican artisan work generates various sources of employment and income for artisans living in rural areas of Acapulco (Forbes, 2014). At the local level, the handicrafts that are offered in "El Pueblito" and "La Diana" have good logistics, accessibility and quality in the products. However, the need for artisans to publicize their products and sell them online was observed in order to increase their sales and give greater dissemination of the existing pieces that are for sale. In such a way that a greater number of visitors acquire quality souvenirs. 
Some artisans commented on the scant support they receive from local and municipal authorities both for the remodeling of their premises and for the promotion of their products, hence "it is necessary to work in conjunction with the Ministry of Tourism and state and municipal governments ”(Hernández, 2013, p.52).

It is a collective feeling that artisans currently need recognition of the dignified activity to which they are dedicated, it is urgent to promote the unique pieces that are made in the seven economic regions of Guerrero. An example is seen in Table 5; in addition to the investment that is made from the municipal tourism directorates, state secretariats, the SECTUR itself, companies and non-governmental organizations.

In Mexico, the presence of coasts, seas and beaches are abundant because nature was lavish in these natural landscapes that the environment offers to the population settled in the vicinity of said natural spaces, and where man, through his various economic activities, does a sustainable use of plant resources, such as coconut trees, water lilies and fish scales, so that artisans carry out an ecosystem offer translated into local artisan souvenirs integrated into social, economic and environmental sustainability (ECLAC, 2019).

It was found that national and foreign tourists, before coming to this beach destination or others, investigate in social networks the landscape attributes of the site, cultural monuments to visit, as well as the beach, nightclubs, cinemas, banking areas, shopping malls. During their stay in the chosen destination, they buy products and with the use of new technology, they georeference the points of interest they visit so that family and friends are aware of the visit and after that stay they exchange experiences and emotions, in addition to making recommendations in their social networks (Majó, 2019).

Handicrafts are tourist products linked to the environment, which is why they contribute to the sustainability of waste and plant resources such as palm, water lily, among others, hence the importance of current generations in the manualoral transmission of techniques to new generations in order to carry out the responsible management of natural and local resources.
In such a way that, by 2030, efforts are aimed at the 17 Sustainable Development Goals, in particular number 11, which refers to the sustainable management of solid waste (Gómez, 2018), as well as vital recycling to reduce the environmental impact in the cities of the world, among them, Acapulco, Guerrero (Figure 12).

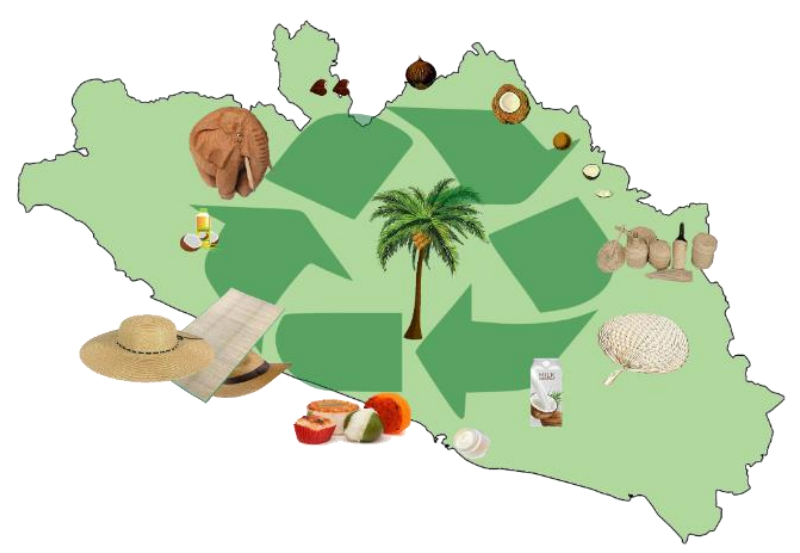

Figure 12 Comprehensive use of Cocos nucífera Source: Rojas, 2020

\section{Acknowledgments}

To the National Council of Science and Technology (Conacyt) for the economic sponsorship for the development of this research through the scholarship in the Master of Science Program: Sustainable Tourism Management (2018-2020) at the Autonomous University of Guerrero.

\section{Conclusions}

The innovation of artisan souvenirs for tourism is an option in sustainable development for artisans, since the souvenirs are of organic origin. From an environmental point of view, the craft diversity lies in the strength of the creativity of Acapulco artisans. Their trade does not harm the environment when it comes to collecting waste and materials that nature itself offers them.

New trends in tourism allow the introduction of handcrafted souvenirs for functional use and with guaranteed quality, such as shampoos and oil for cooking fat-free food, made with materials from the Acapulco region and its surroundings, such as the Emiliano Zapata neighborhood, Renacimiento, La Poza and Plan de los Amates. In such a way that the natural landscape is preserved and the waste used is part of the dead matter and depletion of the low deciduous forest present in this tropical area of the planet. 
During the research process it was detected that one of the points to be strengthened in the development of handicrafts is the marketing stage, since tourists request discounts on the costs at which the products are offered. Therefore, Acapulco artisans know the costs of their inputs, as well as their target market, but feel somewhat unmotivated when tourists do not cover the real cost of their effort.

The tenants commented that they make their crafts, but the hoarders request to trade their products and after the sale they promise to pay them, which in many cases does not happen, to the detriment of the cultural identity of those who make them, the symbol and the cultural meaning of the pieces.

Some artisans from the "El Pueblito" market stated that the artisan products have unique, original and remarkable characteristics, which translates into a competitive advantage for the artisans of Guerrero. However, currently to continue in the market competition they resort to innovation and new designs, such as, for example: making covers for Ipad, covers for laptops, tortilleros, baskets for clothes, bags for girls, cell holders, pens, vases, baskets for fruits, jewelry boxes, portfolios, without sacrificing the elements of identity and tradition.

Designing a craft object requires a process of trial and error, since you have to start with drawings, continue with models and finally the process ends with the prototype (Covarrubias, 2018).

From the economic point of view, handicrafts represent an important source of income for members of indigenous groups that make handicrafts on a small scale with affordable costs.

From the social point of view, it was observed in the field that those who sell the crafts belong to the mestizo race. Those who are in charge of manufacturing belong to the original groups of Guerrero: Mixtecos, Amuzgos, among others.

Social inclusion by UAGro, training and training artisans and other people who want to learn this trade. The artisan souvenirs with their high quality and sustainable innovation, have allowed the Guerrerenses crafts to be recognized regionally / nationally with awards and distinctions to the Guerrerense artisan work.

ISSN-Print: 2007-1582- ISSN-On line: 2007-3682

ECORFAN $^{\circledR}$ All rights reserved.

\section{References}

Arroyo, L. y Terán, S. (2017). Artesanías y recursos naturales. Biodiversidad y Desarrollo Humano en Yucatán. 1(1), 365-367. Recuperado de https://www.cicy.mx/Documentos/CICY/Sitios/Bi odiversidad/pdfs/Cap7/15\%20Artesanias\%20y\%2 Orecursos.pdf

Bomba, F. (2018). Tamaño de la muestra paso a paso. Recuperado de https://www.youtube.com/watch?v=oc8i9g144Y0 Bonfil, P. (2001). De la tradición al mercado: microempresas de mujeres artesanas. México: GIMTRAP.

CEPAL, (2019). Perspectivas del comercio internacional de América Latina y el Caribe 2019: El adverso contexto mundial profundiza el rezago de la región. Chile: CEPAL.

Covarrubias, A. (2018). Artesanas indígenas actualizan diseños para mantenerse en el mercado. Mujer ejecutiva, 1(1), 1-9. Recuperado de mujerejecutiva.com.mx/economia/artesanas-

indigenas-actualizan-disenos-para-mantenerse-enel-mercado/

Forbes Staff (2014). México y sus artesanías en el mundo. Recuperado de https://www.forbes.com.mx > Negocios

Hernández, E. (2013). Turismo y artesanías. En Sales, Francisco (comp.). Las artesanías en México, situación actual y retos. CDMX: CESOP, 57-60.

Lechuga, M. D. R. D., González, R. O., \& Domínguez, I. G. (2020). Estrategias locales desde el turismo rural en la producción de artesanías textiles Mazahuas, San Felipe Santiago, Villa de Allende. Revista de Desarrollo Sustentable, Negocios, Emprendimiento y Educación, 2(4), 1$17 . \quad$ Recuperado de https://www.eumed.net/rev/rilcoDS/04/artesaniasmazahuas.html

Lesur, L. (2006). Manual del guía de turistas. Una guía paso a paso. México: Trillas.

Majó, J. (2019). Tendencias de las Tecnologías de la Información y la Comunicación en Turismo. Conferencia dictada el día 8 de octubre en la Facultad de Turismo, UAGro. México: Inédita. 
Niño, N. (2014). Planeación ambiental aplicada al caso de La Roqueta. México, D. F.: Ediciones Eón.

Niño, N. y Bergeret, R. (2012). Atractivos del turismo cultural en Acapulco. Revista Altamirano. 1(42), 65-80.

Padilla, C.G. \& Tacuri, L. E. (2020). Propuesta de un modelo de gestión turística para los bienes patrimoniales arquitectónicos-religiosos de la arquidiócesis de Cuenca del Centro Histórico de Cuenca, Ecuador. Tesis de Licenciatura En Turismo. Facultad de Ciencias de la Hospitalidad. Universidad de Cuenca. Ecuador. Recuperado de https://core.ac.uk/download/pdf/328376607.pdf

Poveda Llamas. O. (2020). Aprovechamiento turístico de un recurso singular: Albacete y su navaja. Tesis de grado en Turismo. Facultad de Filosofía y Letras. Universidad de Alicante. Recuperado de https://rua.ua.es/dspace/bitstream/10045/107819/ 1/Aprovechamiento_turistico_de_un_recurso_si ngular_Albacete_Poveda_Llamas_Olga.pdf

Quille, K. L. \& Urgilés, N. B. (2020). Plan de exportación de figuras elaboradas en bronce niquelado y cerámica para la Asociación de Artesanos ubicados en Sangolquí, Quito-Ecuador. Tesis de especialidad en Comercio y Finanzas Internacionales Bilingüe. Facultad de Especialidades Empresariales. Universidad Católica de Santiago de Guayaquil, Ecuador. Recuperado de http://repositorio.ucsg.edu.ec/handle/3317/15138

Rojas, A. (2018). Fotografías de Turismo y Souvenirs en los mercados "El Pueblito" y "La Diana" de Acapulco de Juárez, Guerrero. Inédito.

Rojas, A. (2019). Análisis Estadísticos resultantes de los cuestionarios aplicados a los visitantes nacionales y extranjeros en los mercados "El Pueblito" y "La Diana”. Inédito. Ruiz, J. \& Niño, N. (2014). El turismo en las bahías de Papanoa. En Niño, N., Bergeret, R. y Díaz, A. (Coords.). Gestión Sustentable del Turismo. CDMX: PRAXIS-UAGRO.
SAGARPA. (2015). Estudio multidimensional para el aprovechamiento del producto de la Palma de Coco a través del proceso de deshidratado como soporte tecnológico para los cultivos ubicados en la Costa del Pacífico. Octubre. 1(1), 1-64. Recuperado de https://www.gob.mx/cms/uploads/attachment/file/ 346828/Palma-de-Coco-Detallado.pdf

Singón, J. (2016). Apoyar al sector artesanal, mediante un estudio de factibilidad para la implementación de una microempresa productora y comercializadora de artesanías elaboradas con la corteza de coco, en el distrito metropolitano de Quito, 2016. Bachelor's Thesis.

Trujillo, A. \& Arias, L. (2013). El coco, recurso renovable para el diseño de materiales verdes. Ciencia e Ingeniería, 1(14), 93-100.

UNIFEM (1997). Primer Congreso de Mujeres Mayas. Fondo de Desarrollo de las Naciones Unidas para la Mujer. México: UNIFEM. 